\title{
Post-transplantation HTLV-1 myelopathy in three recipients from a single donor
}

\author{
J J Zarranz Imirizaldu, J C Gomez Esteban, I Rouco Axpe, T Perez Concha, \\ F Velasco Juanes, I Allue Susaeta, J M Corral Carranceja
}

J Neurol Neurosurg Psychiatry 2003;74:1080-1084

See end of article for authors' affiliations

Correspondence to: Dr J C Gomez Esteban, Servicio de Neurologia Hospital de Cruces sn CP 48903 Baracaldo,

Vizcaya, Spain:

igomeze@meditex.es

Received

20 October 2002

Accepted in final

revised form

15 February 2003

\begin{abstract}
Objectives: This paper reports for the first time three cases of infection by HTLV-I via organ transplantation; all the organs coming from the same asymptomatic infected donor. The need is considered for the implementation of compulsory screenings for HTLV antibodies on organ donors and on blood banks.

Methods: The determination of antibodies for HTLV-I/II on samples of serum and cerebral spinal fluid from the patients and the donor was performed by enzyme immunoassay and western blot. Analysis of proviral DNA was performed by polymerase chain reaction. To detect changes in the sequence of aminoacids, the tax gene was sequentiated, amplified, and compared with ATK prototype stocks. Spinal cord magnetic resonance imaging, cerebral spinal fluid, and somatosensory evoked potential studies were carried out in all patients.

Results: All three transplanted patients developed a myelopathy within a very short period of time. In all three patients and donor the virus belonged to the Cosmopolitan A subtype. The homology of HTLV-I sequences recovered from the patients and donor was 100\% in all four cases. Proviral load was high in all three patients. The factors that certainly contributed to the infection in the first place, and the development of the disease later, were on the one hand the high proviral load and their immunosupressed condition, and on the other the virus genotype, which proved to be an aggresive variant. However, the analysis of the histocompatibility antigen showed that two of the patients carried an haplotype that has been associated with a lower risk of developing this disease.

Conclusions: It is argued that, although in Spain and other European countries there is not compulsory screening for HTLV antibodies because of the studies that show a low seroprevalence, in view of the cases here reported, and to avoid the serious consequences that such infection has on transplanted patients, compulsory screenings, both on organ donors and on blood banks, should be implemented.
\end{abstract}

S ubacute myelopathy is the primary neurological manifestation of the infection caused by human T lymphotropic virus type I (HTLV-I). ${ }^{1-3}$ This virus, discovered in 1980, was the first retrovirus to be associated with diseases in humans. ${ }^{4}$ Three different genotypes of this virus have been identified: Melanesian (HTLV-I subtype C), Central African (HTLV-I subtype B), and Cosmopolitan (HTLV-I subtype A). The last one is subdivided, in turn, into various subgroups: Transcontinental, Japanese, Western African, and North African. ${ }^{5}$

HTLV-I is endemic to certain areas of the Caribbean, ${ }^{6-8}$ Japan, ${ }^{9}$ and Central Africa. ${ }^{10-13}$ Seroprevalence in these areas is variable, ranging from $3 \%$ to $30 \%$ in adults. ${ }^{14}$ USA and Europe are low prevalence areas $(<1 \%){ }^{3}$ Twenty four cases of infected patients had been identified in Spain up to $1994 .{ }^{15}$ These patients, came either from endemic areas (eight patients), or had had sexual contacts with indigenous people from those regions (75\% of the Spanish born infected patients). At the present time, 51 cases have been reported in Spain. ${ }^{16}$ The large number of infected patients (27 cases) who are native of endemic regions (Africa or South America), is remarkable compared with previous records from 1995. No doubt the inmigratory "boom" of recent years, with people coming from these countries, has contributed to it.

HTLV-I is transmitted through sexual intercourse, breast feeding, or parenterally by means of infected blood transfusions or parenteral drug administration (PDA). ${ }^{17-20}$ Seroconversion is higher in those patients who have received blood transfusions $(40 \%-60 \%)$, than in the cases in which HTLV-I is transmitted through any of the other ways above described. ${ }^{172122}$ About 5\% of the infected patients will show symptoms, and only $0.3 \%$ will develop a myelopathy. ${ }^{23}$ It seems that, in those patients infected by transfusion $(20 \%$ of the seroconverted patients), this condition is more severe and has a shorter period of latency for the development of symptoms (one to two years). ${ }^{24}$ An increased proviral load, immunodeficiency either by coinfection with HIV ${ }^{26}$ or administration of immunosuppressive drugs, and association with certain HLA haplotipes $\left(\mathrm{DRBI}^{*} 0101\right),{ }^{28}$ are among the factors that facilitate the development of the disease. However, other types of HLA $\left(\mathrm{A}^{*} 02\right)$, are thought to have a protective effect. ${ }^{29}{ }^{30}$

In this paper we report for the first time three cases of infection by HTLV-I virus via organ transplantation; all the organs coming from the same infected donor (case l was recently published in a letter to this journal). ${ }^{31}$ All three patients developed a myelopathy less than two years after receiving the graft.

\section{METHODS}

Case 1

This was a 44 year old woman with hepatocarcinoma and alcoholic cirrhosis. In October 1998 she underwent a liver transplant. The patient received post-transplant treatment with tacrolimus. Eighteen months later she noticed weakness in her lower limbs, loss of sensitivity, and difficulties in

Abbreviations: HTLV-1, human T Lymphotropic virus type 1; CSF, cerebral spinal fluid; $M R I$, magnetic resonance imaging; SEP, somatosensory evoked potential; PCR, polymerase chain reaction; ELISA enzyme linked immunosorbent assay 
Table 1 Diagnostic tests

\begin{tabular}{|c|c|c|c|}
\hline & Case 1 & Case 2 & Case 3 \\
\hline Virus serology HTLV in serum & $\begin{array}{l}\text { ELISA and western blot + HTLV I/II } \\
\text { PCR + HTLV-I }\end{array}$ & $\begin{array}{l}\text { ELISA and western blot + HTLV I/II } \\
\text { PCR + HTLV-I }\end{array}$ & $\begin{array}{l}\text { ELISA and western blot + HTLV I/II } \\
\text { PCR + HTLV-I }\end{array}$ \\
\hline Virus serology HTLV in CSF & ELISA and western blot + HTLV I/II & ELISA and western blot + HTLV I/II & ELISA and western blot + HTLV I/II \\
\hline Biochemistry of CSF & $\begin{array}{l}133 \mathrm{mg} / \mathrm{dl} \text { proteins } \\
43 \mathrm{mg} / \mathrm{dl} \text { glucose } \\
9 \mathrm{cells} \\
\mathrm{BOC}-; \lg \mathrm{G}-\end{array}$ & $\begin{array}{l}54 \mathrm{mg} / \mathrm{dl} \text { proteins } \\
43 \mathrm{mg} / \mathrm{dl} \text { glucose } \\
9 \mathrm{cells} \\
\mathrm{BOC}+; \lg \mathrm{G}+\end{array}$ & $\begin{array}{l}35 \mathrm{mg} / \mathrm{dl} \text { proteins } \\
46 \mathrm{mg} / \mathrm{dl} \text { glucose } \\
15 \mathrm{cells} \\
\text { BOC -; } \lg \mathrm{G}-\end{array}$ \\
\hline Virus genotype & $\begin{array}{l}\text { Cosmopolitan A } \\
\text { Transcontinental }\end{array}$ & $\begin{array}{l}\text { Cosmopolitan A } \\
\text { Transcontinental }\end{array}$ & $\begin{array}{l}\text { Cosmopolitan A } \\
\text { Transcontinental }\end{array}$ \\
\hline Proviral load & $>1-2$ logarithms* & 1244 copies/10.000 PBMC & 1644 copies/10.000 PBMC \\
\hline Haplotype HLA & & $\mathrm{HLA}-\mathrm{A} * 02$ & $\mathrm{HLA}-\mathrm{A} * 02$ \\
\hline
\end{tabular}

BOC, oligoclonal bands; PBMC, peripheral blood mononucleated cells; CSF, cerebrospinal fluid. *In relation to asymptomatic patients.

urinating. She failed to report these symptoms. Within two months, it evolved to a complete paraplegia and bladder paralysis. On August 2000, four months after the beginning of the symptoms, she was examined in our department. A complete paraplegia with a sensitive level at D8-D10 was found. Magnetic resonance imaging (MRI) of the spinal cord showed a cervical-dorsal enhancement signal (C2-D10) (fig 1). Brain MRI demonstrated non-enhancing periventricular white matter lesions on T2 weighted images. Tibial somatosensory evoked potentials (SEPs) were absent. Cerebral spinal fluid (CSF) examination showed a moderate pleocitosis of lymphocytic predominance and an increased amount of proteins (table 1). A thorough study, to rule out demyelinating or infectious diseases and vasculitis, was conducted. Serological examination for HIV was negative. Serology test for HTLV-I (ELISA) was positive in blood and CSF. These data were confirmed with western blot. HTLV-I genetic material was isolated by polymerase chain reaction (PCR) in blood. Proviral load was high (there is not an exact figure available). ${ }^{32}$ The patient received a pulse of corticosteroids (methylprednisolone, 1 $\mathrm{g} /$ day, for five days) followed by an interferon alfa course (30 MU/day, for 30 days; in the last week, the dose was reduced because of neutropenia and increased transaminase activities). ${ }^{33}{ }^{34}$ Despite the pharmacological and rehabilitative treatment the patient remained paraplegic.

\section{Case 2}

This was a 54 year old woman with a chronic kidney failure secondary to a chronic pielonephritis: on October 1998 she received a kidney from the same donor as case l. An acute rejection occurred in the immediate postoperative period, which was controlled with methylprednisolone $(400 \mathrm{mg} /$ day, for three days). She then received cyclosporine ( $175 \mathrm{mg} /$ day). Several weeks after the operation, she complained of quivering and unsteady gait, which was attributed to the cyclosporine treatment. In October 2000, 24 months after the kidney transplant, she was examined in our department. On examination she showed moderate pyramidal signs on both lower limbs, although they were slightly more intense on her left lower limb, without a clear motor deficit. Her deep sensitivity was also slightly changed. The rest of the examination was normal. On the spinal MRI, two T2/hyperintense lesions compatible with myelitis were objetivated, one cervical (C2-C4) and one high dorsal (D1) (fig 2). On tibial and median SEPs, latencies between N 13 cervical and N20 parietal of the central conduction were prolonged. CSF examination showed a minor lymphocytic pleocytosis, with increased protein concentration and presence of oligoclonal IgG bands (table 1). HTLV-I serologies (ELISA and western blot) were positive, both on

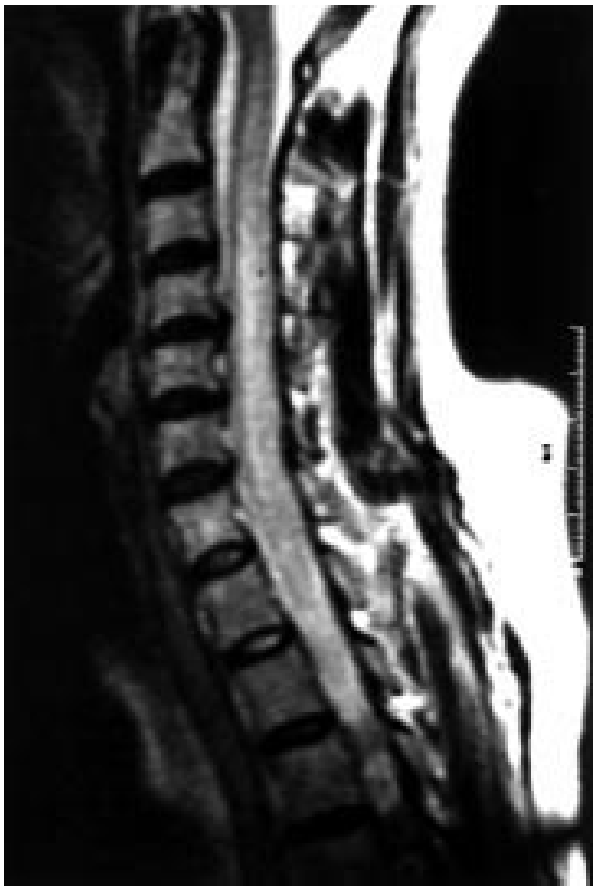

Figure 1 Sagittal T2 weighted spinal cord MRI of patient 1 shows a cervical-dorsal enhancement signal.

blood and on CSF. Blood PCR was also positive. Proviral load showed to be high (1244 copies/10 000 PBMC-nucleated cells in peripheral blood). The patient was treated with corticosteroids (initially methylprednisolone $500 \mathrm{mg} /$ day for four days, and then oral prednisone $30 \mathrm{mg}$ /day for 30 days). The patient has been in a stable condition for a year, but in the past few months pyramidal signs have worsened, with more spasticity in the lower limbs.

\section{Case 3}

The third case was a 57 year old man, diagnosed with chronic kidney failure secondary to glomerulonephritis type A, which motivated a kidney transplant in 1998 from the same donor as patient 1 and 2. His medical history included ischaemic heart disease, hypertension, and hypercholesterolaemia. After surgery the patient followed a treatment with cyclosporine (100 $\mathrm{mg}$ /day). In October 2000, two years after the transplant, the patient reported a fourth month syndrome of unsteady gait, urine incontinence, and paraesthesias of lower limbs. No motor deficit was found on exploration. Tendon jerks in the 


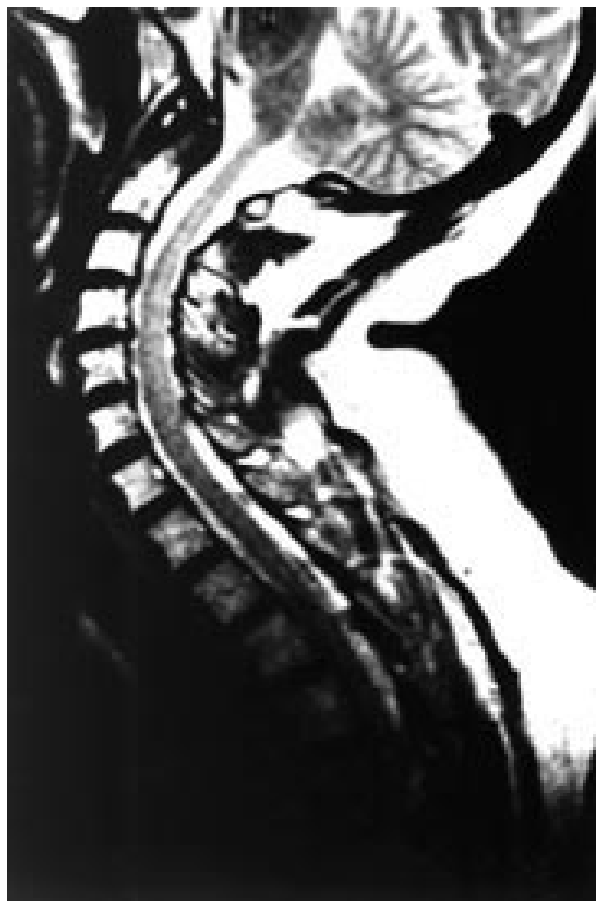

Figure 2 Sagittal T2 weighted spinal cord MRI of patient 2 shows two hyperintense lesions compatible with myelitis: one cervical (C2-C4) and one high dorsal (D1).

legs were brisk with presence of bilateral clonus aquileus. A decreased vibratory sensation in both lower limbs was found. Spinal cord and brain MRI were normal. SEP showed delayed latencies by stimulation of both lower limbs (tibial), and they were normal for both median nerves. A discrete lymphocytic pleocytosis was found on examination of CSF, with no oligoclonal bands (table 1). Blood and CSF serological tests (ELISA and western blot) were positive, as was blood PCR. Proviral load was high (1644/10 000 copies PBMC). The patient was treated with two pulses of methylprednisolone $(400 \mathrm{mg} / \mathrm{day}$, for four days) followed by oral prednisone after each pulse for 30 days. Despite the treatment, his condition has deteriorated during the past few months showing weakness and signs of spasticity and persistence of clonus. The patient refused to start interferon alfa treatment.

\section{Donor's data}

All three patients received organs from the same donor. He was a young man born in Spain, whose mother was born in Venezuela. Retrospectively, it was found that, although she remained asymptomatic, she was seropositive for HTLV-I. The donor died in October 1998 from a road accident. He fulfilled all the legal and medical criteria for the donation. The organ transplantations were performed on the same day of his death. Serological tests for HIV-1, HIV-2, hepatitis B virus (HBV), and hepatitis $\mathrm{C}$ virus ( $\mathrm{HCV}$ ) were all negative. Once the first case was detected, a serological determination for HTLV-I (ELISA and western blot) was performed on stored blood from the donor. Those determinations resulted positive. The liver, both kidneys, the heart, and both corneas were used for transplantation. Heart transplantation was performed in another hospital and we have not data about the recipient status. Serological determinations for HTLV-I in the patients who received the cornea were negative, so they are also omitted here.

\section{Study design}

Determination of antibodies for HTLV-I/II on samples of serum from the patients and the donor was performed by ELISA, which incorporates antigens for HTLV-I and HTLV-II
(Murex HTLV-I+II; Murex Biotech Limited, UK). Later, the positivity was confirmed through western blot (Bioblot HTLV; Biokit, SA, Spain), which incorporates nitrocellulose strips with antigens of HTLV-I and HTLV-II. European Research Network criteria were applied for the interpretation of the western blot.

Analysis of proviral DNA was performed by PCR and sequenced with inner primers and were resolved using an automated DNA sequencer (Applied Biosistems 377 sequencer; PEBiosystems, Foster City, USA). To detect changes in the sequence of aminoacids, the tax gene was sequentiated, amplified, and compared with ATK prototype stocks

\section{RESULTS}

HTLV-1 DNA sequences were successfully recovered, amplified, and sequenced in samples taken from the three HTLV- 1 positive recipients and from the multiorgan donor. In all three patients and donor the virus belonged to the Cosmopolitan A subtype. The sequence of HTLV-I virus's Tax gene was objetivated, showing variations in four nucleotides that have been associated with a higher risk of TSP. The homology of HTLV-I sequences recovered from the patients and donor was $100 \%$ in all four cases, the analyses of the LTR and ENV genes have been described in another paper. ${ }^{35}$ The nucleotide sequence data reported in this study have been deposited in the GenBank sequence database under the following access numbers: AF494238 to AF494245.

Proviral load was high in all three patients. This value was quantified for recipients 2 and 3 (1644/10 000 copies PBMC and 1244/10 000 copies PBMC), and an approximate estimation was made for recipient 1 (>1-2 logarithms) (table 1$)$. None of the patients showed the human leucocyte antigen (HLA), which increases the liability to that infection (HLA $\mathrm{DRBI}^{*} 0101$ ). However, two of the patients (cases 2 and 3 ) were carriers of the haplotype, which apparently has been associated with a decreased risk of suffering the disease $(\text { HLA-A*02) })^{36}$ (table 1).

\section{DISCUSSION}

The three patients we are reporting received viscera from the same donor, carrier of the HTLV-I. It is remarkable that all three patients developed a myelopathy and that this occurred in a very short period of time (within two years).

In this disease inflammatory changes occur simultaneously throughout the entire central nervous system, ${ }^{37}$ thus, perivascular inflammatory changes can be seen in the brain (deep white matter and marginal area of the cortex and white matter $)^{38}$ and in the dorsal spinal cord. Interestingly, these are areas of low blood flow in the spinal cord and brain. Probably, the greater size of the spinal cord lesions in our patients means that they were suffering from this illness in a more severe form.

Japan was the first country to introduce compulsory screening for antibodies in samples of blood from donors. ${ }^{21}$ Afterwards the USA and other European countries (France, Luxembourg, Denmark, Holland, Sweden, and Belgium) have followed Japan's example. ${ }^{15} 39$ In Spain, a study conducted in 1995 concluded that because of the low HTLV-I seroprevalence $(0.002 \%)$ and poor sensitivity of serological determinations at that time, compulsory screening in blood banks was not justified. ${ }^{40}$

Probably one of the determinant factors both for the susceptibility to the infection, and for the development of the neurological disease, was the fact that these patients were receiving immunosuppressor treatment. In Japan, where infection by HTLV-I is prevalent, carriers of the virus are excluded as donors, therefore, this way of transmission has not been reported there. However, long term monitoring of patients who were carriers of this virus and later received a transplant, being therefore immunosuppressed, has been 
published. These reports show that despite their condition, none of them developed a myelopathy, although it must be pointed out that these patients were monitored for very variable periods of time after the transplant ( 1 to 10 years) ${ }^{41}$ Another patient was infected during a heart transplant through contaminated haemoderivatives. ${ }^{25}$ This patient, as in our cases, received immunosuppressor treatment and developed a myelopathy over a period of 18 weeks after the transfusion.

Forty per cent of the patients who develop a myelopathy associated with HTLV-I have received one or more blood transfusions. Seroconversion rate $(40 \%-60 \%)$ and development of the disease are higher for those patients who receive contaminated haemoderivatives than for those infected through other means, like sexual intercourse or breast feeding.

None of our patients was an HLA haplotype carrier, which increases the liability to develop the disease (HLADRB $\left.1{ }^{*} 0101\right){ }^{28}$ However, two of the patients did carry the haplotype HLA-A*02, which seems to grant a protective effect against the disease. ${ }^{29}$ The tax gene of HTLV-I seems to be directly related to the pathogenicity of the virus. ${ }^{42}{ }^{43}$ An analysis of that gene showed that all our patients were infected by the Cosmopolitan A subtype, Transcontinental variety. This variety seems to be related to a more aggressive form and to the development of myelopathy. Recently, Furukawa et al studied the tax gene sequence on 400 patients who had developed an HTLV-I myelopathy, and compared it with that from a group of asymptomatic carriers. ${ }^{44}$ This study showed a difference of four nucleotides in the tax gene, which were related to a high risk of developing a myelopathy. In our patients, tax gene sequentiation showed four changes in the sequence of nucleotides. These changes coincided with those previously described for patients with a higher risk of developing a myelopathy. Nevertheless, the occurrence of "neurogenic" compared with "leukemogenic" strains of the HTLV I retrovirus based on variations of the viral genome is highly controversial.

Moreover, compared with the asymptomatic carriers, all our patients presented increased proviral loads, above 1-2 logarithms. ${ }^{45}{ }^{46}$ This is probably due to the virus being transmitted through viscera, which may involve a higher amount of inoculum.

The cases reported here, are the first in the literature proving that HTLV-I can be transmitted through viscera from a seropositive donor. The fact that all of them suffered a myelopathy within two years of being infected, shows that seroconversion and development of the disease depends to a great extent on the way of transmission. Probably, a high proviral load, associated with the increased inoculums that may involve a viscera, and the immunusupressed condition of the patients who received the transplants, are determinant factors here. It must also be pointed out, that the virus subtype (Cosmopolitan type A) and sequentiation of the tax gene showed that it was an aggressive variant of the virus. ${ }^{44}$

The other two patients were treated with corticosteroids. Such treatment seems to hinder the progression of the disease initially, although in all three cases the condition eventually continued progressing. Our first patient was treated probably too late when suffering a complete paraplegia to prevent an evaluation of the efficacy of corticosteroids or interferon alfa. None of our patients has received an antiretroviral treatment, as the efficiency of these drugs for this kind of infection is still debatable.

In conclusion, our patients demonstrate that an infection by HTLV-1 virus through an organ transplant can have catastrophic consequences for the recipient. We suggest that bearing in mind the epidemiological evidence of an increasing prevalence of HTLV-1 in Western countries because of migratory movements a compulsory serological checking for HTLV-1 should be mandatory for every organ or blood donor.

\section{ACKNOWLEDGEMENTS}

The authors thank Carlos Toro, Berta Rodes, Vicente Soriano for serological determinations, virus typification, proviral load, and HLA analysis.

\section{Authors' affiliations}

J J Zarranz Imirizaldu, J C Gomez Esteban, I Rouco Axpe, T Perez Concha, F Velasco Juanes, I Allue Susaeta, Department of Neurology, Hospital of Cruces, Baracaldo, Vizcaya, Spain J M Corral Carranceja, Department of Microbiology, Hospital of Cruces

\section{REFERENCES}

1 Gessain A, Vernant JC, Maurs L, et al. Antibodies to human T-lymphotropic virus type-l in patients with tropical spastic paraparesis. Lancet 1985; ii:407-10

2 Osame M, Usuku K, Izumo S, et al. HTLV-I associated myelopathy, a new clinical entity. Lancet 1986;ii:1031-2.

3 Manns A, Hisada M, La Grenade L. Human T-lymphotropic virus type I infection. Lancet 1999;353:1951-8.

4 Poiesz BJ, Ruscetti FW, Gazdar AF, et al. Detection and isolation of type $C$ retrovirus particles from fresh and cultured lymphocytes of a patient with cutaneous T-cell lymphoma. Proc Natl Acad Sci USA 1980:77:7415-19.

5 Cann AJ, Chen ISY. Human T-cell leukemia virus types I and II. In: Fields BN, Knipe DM, Howley PM, et al, eds. Fields virology Vol 59 Philadelphia: Raven, 1996:1849-80.

6 Hernandez Ramirez P, Rivero Jimenez R, et al. Very low seroprevalence of HTLV-I/II in Cuba: antibodies in blood donors and in haematological and nonhaematological patients. Vox Sang 1991;61:277-8.

7 Reeves WC, Levine PH, Cuevas M, et al. Seroepidemiology of human T cell lymphotropic virus in the Republic of Panama. Am J Trop Med Hyg 1990;42:374-9.

8 Murphy EL, Figueroa JP, Gibbs WN, et al. Human T-lymphotropic virus type I (HTLV-I) seroprevalence in Jamaica. I. Demographic determinants. Am J Epidemiol 1991:133:1114-24.

9 Morofuji-Hirata M, Kajiyama W, Nakashima K, et al. Prevalence of antibody to human T-cell lymphotropic virus type I in Okinawa, Japan, after an interval of 9 years. Am J Epidemiol 1993;137:43-8.

10 Lillo F, Varnier OE, Sabbatani S, et al. Detection of HTLV-I and not HTLV-II infection in Guinea Bissau (west Africa). J Acquir Immune Defic Syndr 1991;4:541-2.

11 Dumas M, Houinato D, Verdier M, et al. Seroepidemiology of human T-cell lymphotropic virus type I/II in Benin (West Africa). AIDS Res Hum Retroviruses 1991;7:447-51.

12 Delaporte E, Monplaisir N, Louwagie J, et al. Prevalence of HTLV-I and HTLV-II infection in Gabon, Africa: comparison of the serological and PCR results. Int J Cancer 1991;49:373-6.

13 Wiktor SZ, Piot P, Mann JM, et al. Human T cell lymphotropic virus type I (HTLV-I) among female prostitutes in Kinshasa, Zaire. J Infect Dis 1990:161:1073-7.

14 Mueller N, Okayama A, Stuver S, et al. Findings from the Miyazaki Cohort Study. J Acquir Immune Defic Syndr Hum Retrovirol 1996;13 (suppl 1):S2-7.

15 Soriano V, Gutiérrez M, Vallejo A, et al. Infección por HTLV-1 en España. Análisis de 24 casos identificados hasta noviembre de 1994 Med Clin 1995; 105:246-50.

16 Toro C, Rodes B, Aguilera A, et al. Clinical impact of HTLV-1 infection in Spain: implications for public health and mandatory screening. J Acquir Immune Defic Syndr 2002;30:366-8.

17 Manns A, Wilks RJ, Murphy EL, et al. A prospective study of transmission by transfusion of HTLV-I and risk factors associated with seroconversion. Int J Cancer 1992;51:886-91.

18 Hino S, Yamaguchi K, Katamine S, et al. Mother-to-child transmission of human T-cell leukemia virus type-I. Jpn J Cancer Res 1985;76:474-80.

19 Wiktor SZ, Pate EJ, Rosenberg PS, et al. Mother-to-child transmission of human T-cell lymphotropic virus type I associated with prolonged breast-feeding. J Hum Virol 1997;1:37-44.

20 Stuver SO, Tachibana N, Okayama A, et al. Heterosexual transmission of human T cell leukemia/lymphoma virus type I among married couples in southwestern Japan: an initial report from the Miyazaki Cohort Study. J Infect Dis 1993;167:57-65

21 Kamihira S, Nakasima S, Oyakawa Y, et al. Transmission of human T cell lymphotropic virus type I by blood transfusion before and after mass screening of sera from seropositive donors. Vox Sang 1987:52:43-44.

22 Okochi $\mathrm{K}$, Sato $\mathrm{H}$, Hinuma $\mathrm{Y}$. A retrospective study on transmission of adult T cell leukemia virus by blood transfusion: seroconversion in recipients. Vox Sang 1984;46:245-53

23 Kaplan JE, Osame M, Kubota $H$, et al. The risk of development of HTLV-I-associated myelopathy/tropical spastic paraparesis among persons infected with HTLV-I. J Acquir Immune Defic Syndr 1990;3:1096-01.

24 Osame M, Izumo S, Igata A, et al. Blood transfusion and HTLV-I associated myelopathy. Lancet 1986;ii: 104-5.

25 Gout O, Baulac M, Gessain A, et al. Rapid development of myelopathy after HTLV-I infection acquired by transfusion during cardiac transplantation. N Engl J Med 1990;322:383-8. 
26 Rosenblum MK, Brew BJ, Hahn B, et al. Human T-lymphotropic virus type l-associated myelopathy in patients with the acquired immunodeficiency syndrome. Hum Pathol 1992;23:513-19.

27 Lleó A, Planella M, Domingo P. Mielopatía e infección por el virus de la inmunodeficiencia humana. Med Clin 1999:112:423-7.

28 Usuku K, Nishizawa M, Matsuki K, et al. Association of a particular amino acid sequence of the HLA-DR beta 1 chain with HTLV-I-associated myelopathy. Eur J Immunol 1990;20:1603-6.

29 Jeffery KJ, Siddiqui AA, Bunce $M$, et al. The influence of HLA class I alleles and heterozygosity on the outcome of human $T$ cell lymphotropic virus type I infection. J Immunol 2000;165:7278-84.

30 Jeffery KJM, Usuku K, Matsumoto W, et al. HLA allels determine human T lymphotropic virus-I (HTLV-I) proviral load and the risk of HTLV-I associated myelopathy. Proc Natl Acad Sci USA 1999;96:3848-53.

31 Zarranz JJ, Rouco I, Gomez-Esteban JC, et al. Human T lymphotropic virus type I (HTLV-1) associated myelopathy acquired through a liver transplant. J Neurol Neurosurg Psychiatry 2001;71:818.

32 Bangham CRM. HTLV-1 infections. J Clin Pathol 2000;53:581-6.

33 Izumo S, Goto I, Itoyama Y, et al. Interferon-alpha is effective in HTLV-I-associated myelopathy: a multicenter, randomized, double-blind, controlled trial. Neurology 1996;46:1016-21.

34 Taylor GP. Pathogenesis and treatment of HTLV-1 associated myelopathy. Sex Transm Inf 1998;74:316-22.

35 Toro C, Rhodes B, Poveda E, et al. Rapid development of subacute myelopathy in three organ transplant recipients after transmission of human T-cell lymphotropic virus type 1 from a single donor. Transplantation 2003;75:102-4

36 Jeffery KJM, Usuku K, Matsumoto W, et al. HLA alleles determine human T lymphotropic virus-I (HTLV-I) proviral load and the risk of HTLV-I associated myelopathy. Proc Natl Acad Sci USA 1999;96:3848-53.

37 Aye MM, Matsuoka E, Moritoyo T, et al. Histopathological analysis of four autopsy cases of HTLV-l-associated myelopathy/tropical spastic paraparesis: inflammatory changes occur simultaneously in the entire central nervous system. Acta Neuropathol (Berl) 2000;100:245-52.

38 Kira J, Fujihara K, Itoyama Y, et al. Leukoencephalopathy in HTLV-I associated myelopathy/tropical spastic paraparesis: MRI analysis and a two year follow-up study after corticosteroid therapy. J Neurol Sci $1991 ; 106: 41-9$.

39 Courouce AM, Pillonel J, Lemaire JM, et al. Seroepidemiology of HTLV-I/II in universal screening of blood donations in France. AIDS 1993;7:841-7.

40 Soriano V, Mas A. Riesgo actual de transmisión de retrovirus por transfusiones. Sangre 1995;5:407-16.

41 Nakamura N, Arakaki Y, Sunagawa H, et al. Influence of immunosuppression in HTLV-1-positive renal transplant recipients. Transplant Proc 1998; 30:1324-6.

42 Niewiesk S, Daenke S, Parker CE, et al. Naturally occurring variants of human T-cell leukemia virus type I Tax protein impair its recognition by cytotoxic T lymphocytes and the transactivation function of Tax. J Virol 1995;69:2649-53.

43 Nakane S, Shirabe S, Moriuchi R, et al. Comparative molecular analysis of HTLV-I proviral DNA in HTLV-I infected members of a family with a discordant HTLV-l-associated myelopathy in monozygotic twins. J Neurovirol 2000;6:275-83

44 Furukawa Y, Yamashita M, Usuku K, et al. Phylogenetic subgroups of human T cell lymphotropic virus (HTLV) type I in the tax gene and their association with different risks for HTLV-I-associated myelopathy/tropical spastic paraparesis. J Infect Dis 2000;182:1343-9.

45 Nagai M, Usuku K, Matsumoto W, et al. Analysis of HTLV-I proviral load in 202 HAM/TSP patients and 243 asymptomatic HTLV-I carriers: high proviral load strongly predisposes to HAM/TSP. J Neurovirol 1998;4:586-93

46 Manns A Miley WJ, Wilks RJ, et al. Quantitative proviral DNA and antibody levels in the natural history of HTLV-Infection. J Infect Dis $1999 ; 180$ : 1487-93. 